\title{
SUFISTIC LANGUAGE STYLE IN AL-QUSHAYRI'S NAHW AL-QULUB
}

\author{
Rizki Fathul Huda, Cahya Buana
}

\author{
rizki huda19@mhs.uinjkt.ac.id, cahya.buana@uinjkt.ac.id \\ Graduate School UIN Syarif Hidayatullah Jakarta \\ West Tangerang, Banten, Indonesia
}

\begin{abstract}
This study aims to reveal the forms of language style used in "Nahw al-Qulub al-Kabir," the work of al-Qushayri with aesthetic values. It also intends to reveal the meaning effects implied in the language forms. This study uses a stylistic approach in analyzing text's language style, especially at the construction of the morphological level, syntax, and imagery. This research shows that the language style constructs the morphological level through word selection, word forms, and movement from one-word form to another. At the syntactic level, there are unusual sentence patterns and high intensity of using ma mausul as khobar. At the imagery level, al-Qushyari uses many patterns of isti'arah, tashbih, kinayah, saja', iqtibas, and tauriyyah. The extraction of meaning effect also carries a solid sufistic teachings dimension, including takhalli, tahalli, tajalli, ma'rifat, maqam jama' and farq, and the teachings of Akhlaqi Sufism.
\end{abstract}

Keywords: Nahw al-Qulub, al-Qushayri, Stylistics, Sufism

\section{INTRODUCTION}

In Nahw al-Qulub, al-Qushayri presents an anti-mainstream explanation of nahw rules. It is called anti-mainstream because the primary goal of the nahw study is to discuss the position of each word and the change at the end of the word (i'rab), which can be static (mabni) or dynamic (mu'rab) depending on the influencing factors ('awamil) (Al -Ghalayaini, 1994, p. 23). Meanwhile, the Nahw al-Qulub is ijtihad of al-Qushayri delves into the esoteric message hidden beneath the nahw rules.

Carter (1997, p. 24) initially criticized the esoteric meaning of the independent nahw text as unreasonable and strange because it was thought to force the interpretation of nahw rules into the frame of Sufism, both of which had no relevance. Carter's (ibid.) point of view is supported by an argument stating the contradiction between nahw, which has exoteric dimensions, and tasawwuf, which has esoteric dimensions. Furthermore, Nahw purifies the zahir (physical), whereas Sufism purifies the heart of all its diseases. Finally, there is a significant gap between ontology and axiology.
Sumarna (2019) later refutes this viewpoint. He concludes that, using a semiotic approach, Qushayri's efforts in interpreting the esoteric rules of nahw result from creative thinking or innovative ijtihad. Nahw texts contain multiple layers of meaning that can be decoded using connotation and denotation theories. This interpretation, he claims, is due to the inevitability of Arabic, which has a plethora of meanings. In addition, al-Qushayri, as a Sufi, did this deftly and subjectively, bringing him into the Sufistic dimension. This study strengthens several arguments in favor of Qushayri's interpretation of the nahw text. Ivanyi (2006), for example, concludes that Qushayri's Sufistic interpretation of the nahw rule is evidence of a shift from exoteric to esoteric phenomena. According to Baalbaaki (2008), the combination of nahw and tasawwuf results from creative thinking. According to Chiabboti (2009), Qushyari's efforts opened the door to new horizons in studying Arabic grammar related to metalinguistics. Longo (2011) adds weight to the argument by stating that the foundation of interconnectedness between Sufism and nahw has been built 
through a sufistic interpretation of nahw rules using the paradigm of grammatical reality with sufistic intuitive interpretation (Sumarna, 2019, p. 271).

The topic of this article, Nahw al-Qulub, has caught the interest of researchers to examine it using a stylistic approach. Qushayri did not simply use the text of nahw as a framework for conveying his Sufism thoughts, which is distinct from other Sufism works and it only carries a dimension of Sufism in his interpretation of the rules of nahw. On the other hand, the language presentation carries an aesthetic dynamic rarely found in other nahw works. Meanwhile, almost all nahw works are presented in a very formal style.

When viewed from the perspective of balaghah, the terms in nahw are translated into stiff language, far from the beauty of language style of either ma'ani, bayani, or badi'. The aesthetic dynamics of language include poetry, a figure of speech, and metaphors, all of which are frequently used by Sufis in their writing. The collision of the nahw text and the Sufistic meaning results in a presentation and delivery style rich in the values of the beauty of language style. As a result, it prompts researchers to investigate it using figurative language, also known as stylistics. As a result, the study in this article focuses on revealing the stylistic level of morphology, syntax, and imagery in the Nahw al-Qulub text.

\section{STYLISTIC ORIENTATION IN SUFISTIC WORKS}

Stylistics is derived from the English word "style." Stylistics is a body of knowledge that uses linguistic parameters to examine language speech in work (Qalyubi, 2017, pp. 12). In a nutshell, stylistics is the study of how an author expresses himself in his work. The disclosed method can be studied at the level of selecting words, phrases, and clauses (Yasin, 2016, p. 198).

The study of stylistics in Nahw al-Qulub in the context of this research is the knowledge used by researchers in investigating how alQushayri expresses his esoteric meaning of the nahw rules contained in his work. The stylistic aspects studied in Nahw al-Qulub are the same as the general aspects studied.

Stylistics known in Arabic as al-Uslub, and according to Ahmad Muzakki, is a writer's way of describing what is in himself to be conveyed to others by using certain linguistic expressions or with a unique linguistic arrangement so that the intended meaning becomes conveyed into the soul of the reader (Muzakki, 2009, p. 16). Many Arab intellectuals use the study of 'ilm al-balaghah, Arabia's original scientific tradition, to refer to the study of al-Uslub. The study of al-balaghah is very concerned with situations and conditions (muqtadha al-hal). The term muqtadha al-hal appears to be very similar to mawqif. Similarly, balaghah's view of muqtadha al-hal is stylistically equivalent to mawqif's ('Ayyad, 1992, p. 43).

\section{Stylistic Analysis Level}

In general, stylistic analysis of the Nahw al-Qulub text is carried out by researchers through several levels of analysis. The researchers believe that its application is tailored to the subject of study. For example, the level of phonological analysis that appears dominant when used to analyze poetry or poem but is rarely used in prose analysis. As a result, in the context of this study, the researcher will only present a few levels of analysis based on the results of reading techniques used in the data collection method. This level of analysis is regarded as dominant in analyzing the Nahw al-Qulub text as a research object.

\section{Morphology (al-mustawa al-sharfi)}

The scope of morphological level is extensive but briefly covers at least two aspects. The first aspect is the aspect of choosing the form of the word (al-ikhtiyar alsighah), while the second one is the aspect of moving from one-word form to another (al'udul bi al-sighah 'an asl al-siyaqi) (Qalyubi, 2017, pp. 93-94).

\section{Syntax (al-mustawa al-tarkibi)}

The level of syntactic analysis includes sentence structure patterns (al-jumal alnahwiyyah) which include the theory of i'rab and word positions, repetition of words or sentences (al-tikrar), or the ideas behind the use of specific sentence structures. The arrangement of sentences (tarkib) is the smallest part of preparing the functional meaning of a linguistic text. The critical role of nahw in composing various sentence structures is interconnected to give rise to a 
whole unified meaning. In addition, the syntactic level analysis does not only deal with the function of a word, whether as a subject, predicate, or object. Far from it, syntactic analysis has a function construction filled with meaning. Thus, the construction of a word's function at the syntactic level gives the meaning effect of the word's role in the sentence, grammatical semantics (Arsyad, 2016, p. 169).

\section{Imagery (al-mustawa al-tashwiry)}

This level is a form of expressing an abstract idea or ideas of speakers, the emotions of the speaker's soul, events, and other human nature in the form of a picture that can be felt (Nawafi, 2017, p. 243). This level of imagery analysis is closely related to the discipline of 'ilm al-Balaghah. There are three main chapters in 'ilm al-balaghah as the theoretical basis of imagery level in stylistic analysis. Among them are 'Ilm al-Bayan, 'Ilm al-Ma'ani, and 'Ilm alBadi'.

\section{Al-Qushayri's Intellectual Dynamics in Sufism and Nahw}

Sufism, according to al-Qushayri, is not something that is additional or provides the content of the Qur'an and Hadith but instead is a form of concrete abstraction about the greatness of the contents of the Qur'an. Many people are preoccupied with disputes over differences of opinion regarding a particular law in terms of jurisprudence. Thus, the negligence of the nature of the worship practice itself is a vital essence and is a concern for the companions and scholars of the Salaf (Zahra, 2018, p. 57-59). Al-Qushayri's contribution to the spread of Sufism was entirely accurate, but it did not make him close. $\mathrm{He}$ is very inclusive and has a great interest in playing an active role in conveying esoteric messages to the general public. So that Sufism is not only limited to the theoretical and practical level but penetrates the dimensions of reasoning, which are generally inaccessible to ordinary people (Heck, 2006, p. 253).

The construction of nahw Sufism formulated by al-Qushayri and several other Sufi figures who did the same thing seems to be motivated by the penetration and doctrine of Sufism. Sufism from Sufi figures has always been the main foundation in Sufi doctrines associated with various phenomena and symbols that are material. So that various material forms such as text, language signs, and other forms can be used as media in transforming Sufistic messages into it (Maulana, 2019, p. 26).

The construction of Qushayri's nahw tasawuf in interpreting the nahw rules received quite heavy criticism, especially from positivism circles. The view of the Sufis is something that is rejected by the scientific eyes. Moreover, the empiricism paradigm assesses scientific products based on sensory observations and proven scientifically. So that, the intellectual products of the Sufis get less appreciation and support from people who reject them. The attitude of meaning by the Sufis to linguistic texts, both general texts, and the Qur'an, is considered arbitrary and absurd ijtihad (Hogendijk \& Sabra, 2003, p. 50).

However, this view, of course, gets rebuttal from those who support the work. The system of Sufi teachings based on the Qur'an becomes a reinforcement for the credibility of the Sufis in interpreting esoteric texts according to their expertise. It is evidence of the urgency of esoteric interpretations of a text (Mojaddedi, 2000, pp. 37-38).

Apart from the above debate, the meaning of Qushayri's nahw tasawwuf is a product of interpretation of the meaning and esoteric message of the nahw symbol produced on a scientific basis as in scientific and procedural methods. The main principle in the meaning of Qushayri's nahw tasawwuf is the concept of ishari, which is based on several things. Among them are the power of intuition, linguistic rationality, imagination, creativity, and the elaboration of symbolic interpretation and esoteric interpretation (Sumarna, 2019, p. 98). The mechanism of meaning through the concept of ishari that al-Qushayri carries out is not arbitrary, and the result is not absurd. Moreover, the domain of meaning of a text is a tentative ijtihad and the truth is relative, without having to be monopolized by only one party. Furthermore, absolute truth belongs to God alone.

\section{METHOD}

The researcher employed the reading and writing techniques in collecting data from the Nahw al-Qulub al-Kabir's text. In the process of data analysis, researchers used the 
analytical method popularized by Miles and Huberman, with the analysis technique carried out at the time of collecting data and postcollecting data (Miles \& Huberman, 1994, p. 30).

\section{DISCUSSION \\ Stylistics in Nahwu Zahir and Bathin}

Imam al-Qushayri started his idea of esoteric meaning of nahw by presenting the distinction between nahw al-zahir and nahwu al-bathin. In his idea, the nahw al-bathin is: : نحو الحق مخاطبة القول وحميد بالقلب القول حميد إلى القصد الباطن

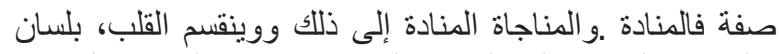

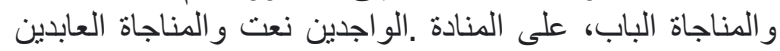

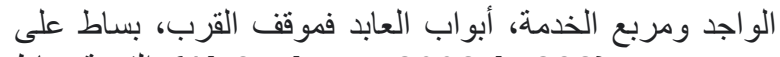
القربة بساط (Al-Qushayri, 2008, h. 298).

Nahw for al-Qushayri, of course, is not just a nahw related to grammatical rules. However, nahw, in an esoteric context, is a rule of the heart (qalb) that aims to train a servant to use his heart in saying commendable words. Praiseworthy words (hamid al-qaul) for alQushayri can only be manifested in the communication of a servant with Allah through the language of the heart absolutely under any conditions.

Shahrizal Mahpol's research states that al-Qushayri's efforts are thought to inspire his readers to have a balance between zahir and bathin. Even this concept can be used as a unique material for teachers in delivering nahw lessons to their students (Mahpol, 2017). In another view, pragmatically, al-Qushayri's goal to integrate nahwu zahir and batin proves that Sufism is not an exclusive science. It is an open science to meet other sciences (Maulana, 2019).

\section{Morphological Stylistic (Word Choice)}

Al-Qushayri chose the word حميد the form of the word of فعيل. This wazan can be another alternative for ism maf'ul and show the hyperbole form (sighah al-mubalaghah) of ism fa'il. So, the word حميد has the same meaning with or it is a sighah al-mubalaghah from حامد. The researchers see the reference of the word حميد with حميد weans حميد However, the choice of the form implies showing a commendable utterance that is continuous and applies absolutely in all conditions and contexts (al-mahmud fi kulli hal). Therefore, the choice of word is an appropriate option, by looking at the view of al-
Qushayri s tatingthat the commendable words are the various words and words of a servant with his Lord in the language of the heart. The choice of this word form shows that the concept of commendable words, although outwardly, can be realized in everyday life. It turns out that commendable words with the highest aesthetic value are all utterances made in dialogue with Allah SWT. It is an implementation of the divine aesthetic. The beauty lies in praising Allah and the experience of a servant at the ma'rifat stage with Him through inner vision.

نعت and صفة The choice of words between which is based on (mudhaf) on two different words, gives a signal that there are differences in characteristics or signs between an expert in worship ('abid) and people who have experienced an encounter with Allah (wajid). Between na'at and shifat are synonymous words. However, according to Ibn al-Qayyim al-Jawziyyah, the two have differences. Firstly, $n a^{\prime} a t$ refers to something that is always rebuilt and regenerated (tajaddud) or is constantly repeated and renewed. While shifat shows something steady and permanent (thabitah lazimah). Secondly, na'at denotes something more specific, while shifat shows something general (Al-Jawziyyah, n.d., pp. 361-362). Finally, Ibn al-Athir adds that na'at denotes something positive, and shifat can show something positive or negative. From this description, it can be understood that there are differences in caste position between worshippers (al 'abid) compared to people who have experienced an encounter with Allah, in Qushayri's view (Ibn al-Athir, 2000, p. 926).

\section{Syntactic Stylistic (Sentential Style)}

Mubtada in the text above is formed from the composition of idhafah in the form of the words and نحو and الباطن. In contrast, the khabar is the word القصد that is rarely used, because generally khobar is formed with the ism nakirah. The next uniqueness in the text above is Qushayri's ingenuity in using a combination of idhafah ma'nawi and idhafah lafdhi in making a perfect sentence. By occupying the position of mubtada', this structure is a form of idhafah lafdhi with the word حميد as mudhaf in the form of ism maf'ul and the word القول as mudhaf ilaih. In comparison, the khabar is in the form of an idhafah ma'nawi structure, namely the structure of الحق مخاطبة with the 
word مخاطبة as mudhaf in the form of masdar and the word الحق as mudhaf ilaih.

Then the structure of mubtada' dan khabar is also equipped with idhafah ma'nawi structure in the form القلب لسان. The structure of the sentences arranged by al-Qushayri looks long-winded by mentioning the word القول حميد twice. The word can be abbreviated with dlamir (وهو) or even simply add alif lam li al'ahd al-madhkur (ال) to the word to imply the same meaning, or even the two numbers of ismiyyah above can be summarized by مخاطبة وهو القول حميد إلى القصد الباطن فنحو wontioning to avoid wasting words and the impression of long-winded. However, in this context, it is reaffirmed that this is a form of alQushayri's creativity in presenting a wealth of beautiful sentence patterns.

\section{Stylistic Imagery (Isti'arah)}

This text describes the extraction of the esoteric meaning of $n a h w$, which is realized by al-Qushayri in two forms, namely al-munadah and al-munajah. There is the use of al-isti'arah in the sentence فموقف العابد أبو اب الخدمة the position of worshipper (al 'abid) lies at the door of devotion". The word الخدمة is musta'ar lah or musyabbah mentioned in this text. In comparison, musta'ar minhu or musyabbah bih is the word البيت that is not shown. So through qarinah lafziyyah in the form of the word أبواب (doors) which is al-rumuz min lawazim (common nature) of البيت (house) which has a physical door, it shows the existence of majaz in the sentence pattern. In contrast, الخدمة which has the translation of devotion is something that usually does not have a physical door. This isti'arah pattern is included in the category of al-isti'arah al-makniyyah.

The pattern of al-isti'arah al-makniyyah is also found in the snippet of the sentence "and a beautiful place for people who meet Allah lies in the rug of closeness to Him". The word القربة is musta'ar lah or musyabbah mentioned in this text, while musta'ar minhu or musyabbah bih is the word (noble and honorable room) which is not shown. So that through qarinah lafziyyah in the form of the word بساط (rug) which is al-rumuz min lawazim (common nature) of الغرفة المكرمة والمحترمة which usually has a physically beautiful rug in it, it shows the existence of majaz in the sentence pattern. While القربة which has a close translation (between a servant and God), is something that usually does not have a physically beautiful rug.

The next type of al-isti'arah is al-isti'arah al-tasrihiyyah which is contained in the word مربع as musta'ar minhu which is mentioned in the sentence. The word marba' is lexically a word that shows the meaning of a special place for someone who enjoys spring (rabi'). The word marba 'is mushabbah bih of an unmentioned mushabbah, which is a good and noble place (الموفق المكرم والمحترم). Indeed, alQushayri wanted to describe the position of a servant with his Lord. The worship of a servant (al-'abid), the position or place for him, is described with mauqif. While the position or place for people who have met Allah (al-wajid), is described with the word marba'. The فموقف العابد أبواب الخدمة، . وموقف الو اجد التي كالمربع بساط القربة It is a distinction between the description of the beauty of a place or the position of 'abid and wajid before Allah.

\section{Stylistics in Maqam Jama' and Farq}

The theory of mabni and mu'rob in nahw becomes the basis of al-Qushayri's philosophical thought in delivering an understanding of the Sufi concept called jama' and farq. Ahmad bin 'Abd al-Karim said that in a semantic view, the concept of i'rob rafa' is interpreted as a sign of the high degree of human being when successfully accepted in the divine realm. Nashab is defined as a moment of self-purification of a servant's submission to his Lord. Khafdh is defined as a servant's submission to his Lord, weak and always needing Him. Meanwhile, jazm is defined as the belief coming from God, making the servant does not need anything but his Lord (Karim, 2017).

In the Arabic version, the researchers extract the statement of al-Qushayri as follows: ونطق القلب إما بلفظ بر اعى فيه توقيف الحق، أو قالة

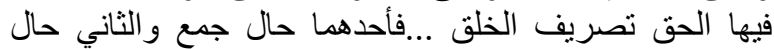

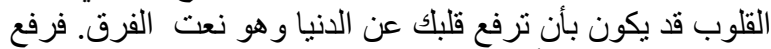

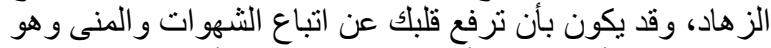

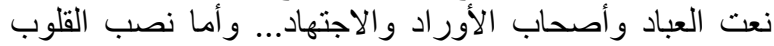

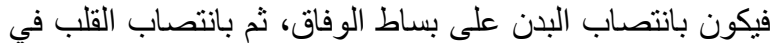

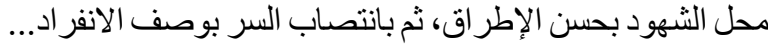
و وأما خفض القلوب فيكون باستشعار الخجل، و واستدامة الوجل.

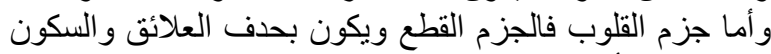
تحت جريان أحكام الحقيقة من غير إخلال بشيئ من آداب الثريعة الثرن (Al-Qushayri, 2008, p. 301-303). 
Jama' is the emergence of divine meanings and the tenderness of the concept of ihsan. A person who experiences the condition of jama' witnesses himself before Allah through delegated actions from af'al Allah SWT. Meanwhile, farq is all the efforts of a servant in enforcing the ritual of 'ubudiyyah and behavior outlined as a human being. These two concepts arin verseated in the verse إياك نعبد which represents the farq condition, and the verse إياك نستعين which represents the condition of the jama' (Al-Qushayri, 1989, pp. 144-145).

\section{Morphological Stylistics (Word Choice)}

Al-Qushayri's intellectuality in the field of Sufism inspired him to express ideas about the stages of spirituality (maqamat) of a salik through an explanation of the article al-i'rob wa al-bina'. The use of the word قالة was chosen by al-Qushayri compared to the lafadz قولة or ar ar which is the original form of ism masdar from قال. The lafadz used by al-Qushayri has undergone a process of replacing the letter 'illat in the form of wawu with alif. The most basic reason in the science of nahw is that it avoids the heavy pronunciation of wawu (daf'an liththiqal) because wawu is considered the heaviest illat letter. At the same time, alif is the lightest illat letter. In addition, the word فأحدهما was chosen by al-Qushayri over the word الو or ma'thuf.

Interestingly, of course, because alQushayri wants to convey numbers that show the order of the 1st and 2nd. It is proven by the existence of the following sentence connection that begins with the word والثاني. The choice of the word فأحدهما indeed becomes nonnormative if you look at the rules of structure ma'thuf dan ma'thuf'alaih.

The choice of word forms contained in the article al-i'rob wa al-bina' is also seen in interpreting i'rab rafa', nashab, khafd, and jazm. In this case, al-Qushayri uses several word forms (sighah), the keywords interpreting each i'rab term. Firstly, rafa' was chosen by him the form of the word fi'il mudlari' thulathi mujarrad contained in the word ترفع. Secondly, in interpreting nashab, alQushayri chooses to use masdar from wazan افتعل in forming the word انتصاب. This word could have used the masdar thulathi mujarrad form only (نصنب). This choice is not without reason because wazan or the base form of fiil mazid has implications for particular meanings. Thirdly, the word استشعار which follows wazan استفعال was chosen to explain the meaning of khafd. Fourthly, the term jazm is not interpreted with keywords in verbs (fiil) or ism musytaq, but with ism jamid. Each understanding of the division of i'rab uses keywords with different word forms.

The choice of the word forms باستشعار واستدامة الوجل feeling ashamed) and الخجل (Wob ) (worried about mental loss) shows that the realization of both requires a reasonably laborious effort (taklif). Moreover, it proves how aesthetically pleasing al-Qushayri's language is in choosing words. As if he was advising the novice salik "ya memang susah, tetapi berusahalah untuk senantiasa merasa malu dan khawatir akan kerugian batin". "yes it is difficult, but try to always feel ashamed and worry about mental loss". Because, with these commendable attitudes, it will give birth to spiritual aesthetics.

\section{Syntactic Stylistics (Sentential Style)}

Conjective structure of sentences (ma'thuf and ma'thuf 'alaih) in standard rules prioritizes the existence of compatibility between the two in terms of word types. For example, if $m a^{\prime}$ thuf is a verb (fiil), then ideally ma'thuf 'alaih is also in the form of fiil. Likewise, if ma'thuf is an ism (noun), then ideally the ma'thuf 'alaih is also an ism. However, al-Qushayri does not prioritize the compatibility between ma'thuf and ma'thuf 'alaih in forming a conjective structure. This can be seen in his explanation of the rafa' forms

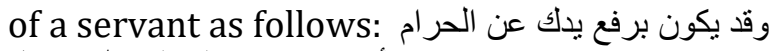

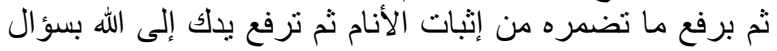
الجاجات ثم ترفع الحاجات عند إحكام المحبة المبال

The conjective structure in the sentence above is called 'athaf nasaq. It is the structure of 'athaf (conjunction) by utilizing the letter 'athaf which is between ma'thuf and ma'thuf 'alaih. The sentence above contains a repetitive conjective arrangement. First, ma'tuf 'alaih is in the form of the word برفع يدك ها and the ma'tuf is with the letter "ataf is ثرفع ما. Second and third respectively, there are ma'tuf in the form of the words ترفع يدك and ترفع الحاجات. In terms of word form, the second and third ma'thuf are masdar, different from the first ma'thuf and ma'thuf 'alaih which are fi'il mudlari'. This difference in word form implies a difference in meaning. 
Meanwhile, ideally in the structure of 'athaf nasaq, it requires the compatibility of the two words in terms of i'rab and meaning. The choice of the word ترفع representing a heart that consistently refuses to sink into the sea of worldly humiliation and lust is an aesthetic in itself compared to the glittering beauty of the world itself. The realities that occur for those lulled by the glittering world's transient beauty bring them to the abyss of humiliation. Moreover, it is very well known that love for the world is the culprit of all chaos and evil.

\section{Stylistic Imagery (Isti'arah)}

In the text explaining $a l-i$ 'rab and albina', al-Qushayri presents a sentence pattern containing al-isti'arah al-makniyyah. The word ونطق القلب إما بلفظ يراعى فيه in the sentence القلب is a musta'ar lah or musyabbah. In contrast, musta'ar minhu or musyabbah bih is the word اللسان (lisan) which is not mentioned. Qطق (pronunciation or speech) is al-rumuz min lawazim (common nature) of اللسان. At the same time, القلب (hati) (heart) is something that usually cannot pronounce various kinds of words or sentences properly verbally. The same pattern is also used in the following sentence which is تسمع بقلبك. The difference is only in musta'ar minhu and al-rumuz min lawazim, constructed in the two sentences. Musta'ar minhu which is not mentioned in this sentence is الأذن (ear). At the same time, alrumuz min lawazim, which shows the nature of musta'ar minhu is the word تسمع (hearing).

The word بخف الجناح lexically can be translated as "lowering the wings" but actually what is meant is to humble oneself by being gentle. The term خفض الجناح is also found in the surah al-Isra 'verse 24 as follows. Meanwhile, in Lathaif al-Isharat, al-Qushyari interprets it as good behavior to both parents, gentle speech, loyal devotion, responsiveness to both parents, not bothering them both, and patient in carrying out orders from both of them. Assuming that al-Qushayri borrowed the term khafdz al-janah as in the verses of the Qur'an, وقد يكون بخفض الجناح (أي ولي طن

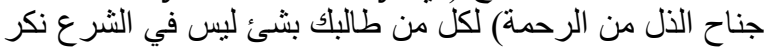
من غير رد و لا نزع ولا إبرام واستكره لئكي. Therefore, he

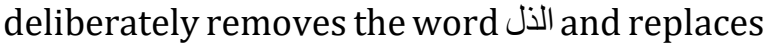
it with the addition of alif lam (ال) on the word الجناح. Whereas the word is musta'ar lah or musyabbah, while the musta'ar minhu or musyabbah bih which is not mentioned is the word الطير (bird). Since qarinah lafziyyah is in the form of the word جناح (wings) which is alrumuz min lawazim (common nature) of الطير, الذل (lowliness) is something that usually does not have physical wings. Therefore, deviations from the rules of al-isti'arah al-makniyyah are carried out by al-Qushayri in constructing the text above. The usual pattern of al-isti'arah almakniyyah is to mention musta'ar lah and hide musta'ar minhu. Meanwhile, in the laim pattern, al-Qushayri hides the two torofs. However, the addition of alif lam (ال) to the جناح indicates that what is meant is الجناح الرجمال

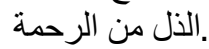

Aesthetics Ruhaniyyah, related to the morals of Sufism and morality, is taught by alQushayri for the salik. Among the morals that must be held tightly by the salik is always to be gentle to anyone. This gentle attitude is aesthetically described in the form of a metaphor (isti'arah) such as lowering the wings (بخف الجناح), for the nature of feeling yourself superior or superior to others usually dominates a person's heart which can be imagined with a flap of wings. It is the habit of birds feeling superior among other creatures or their prey by showing off the beauty and greatness of their wings. Al-Qushayri asserts that the attitude of feeling great (ta'ajjub) in front of other creatures lowers the degree of a servant in front of Allah SWT.

Likewise, there is a pattern of al-isti'arah al-makniyyah in the embodiment of jazm in Nahw al-Qulub described in several forms ويكون جزم which are revealed in the sentence القلوب قطعها عن خطر ات المنى فإن الأماني و المعنى منضادة،

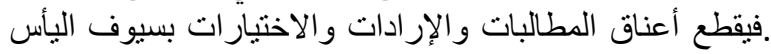
"(jazm in Nahw al-Qulub) can be a disconnection (freedom) of the heart from the influence of desires because desire is always contrary to meaning. Therefore, a servant must cut the neck (connection) between the heart and demands, wills, and desires with the sword of self-surrender.

The word المطالبات is musta'ar lah or musyabbah mentioned in this text. But, then, musta'ar minhu or musyabbah bih is the word الإنسان (human) which is not shown in the text. So, through qarinah lafziyyah in the form of the word أعناق (necks), which is al-rumuz min lawazim (common nature) of الإنسان which is customary to have a neck, it shows the existence of majaz (metaphor) in the sentence 
pattern. Meanwhile, المطالبات which has a close translation of desire or wishful thinking is something that usually does not have a physical neck. Thus, the neck intended for wishful thinking is an imaginative neck.

The derivative of implementing the farq concept in the form of $m u^{\prime} r a b$ rules shows that a servant can actualize his position in the farq point through four kinds of mu'rab forms, namely rafa', nashab, khafd, and jazm. The four forms of actualization of farq through the rules of mu'rob are based on the soul (al-nafs) and centered on the heart (al-qalb).

Rafa' shows that a servant must try his best and put all his abilities consciously and sincerely into forming a heart that always tries to avoid despicable traits. Among them are the love of the world and enslaving oneself to the world. In navigating the farq order in the heart of a servant, he must have the character of asceticism. Zuhd, according to al-Junaid is an attitude of rejecting the heart towards the glitter of the world, not happy and proud of what is achieved from a worldly thing, and not sad and feeling lacking for what is not achieved (Anwar, 1995, p. 65). The next despicable trait is following the lusts and desires of the mirage. Therefore, a servant is required to strive so that his heart is not enslaved by lust and mortal dreams. Morals like this are the na'at of worshippers ('ibaad), as well as wirid and mujahadah actors. Finally, humans are required not to claim their superiority. Therefore, a servant must strive so that his heart does not feel superior, the most special, and feels he influences something. In psychology, this trait is called the superiority complex, which feels much greater or better than others and looks down on others. Therefore, to avoid these properties, an anesthetic is presented in the form of an inferiority complex, namely the feeling of remaining inferior and feel weak (AyimAboagye, 2018, p. 6692).

Nashab becomes the actualization of the farq concept in its application in the form of preparations (بانتصاب) which have previously been prepared in the rafa' concept. This preparation is in the form of a heart condition which includes several qualities that are considered commendable in the view of Sufism (al-akhlaq al-maheasy). Namely, the readiness of the body in taking the path of obedience, the readiness of the heart in submission to Allah
SWT, and the readiness of sirr to focus on efforts to mushahadah to Allah swt

Khafd becomes the actualization of the concept of farq in its application in the form of a servant's demands on his heart to feel (باستشعار) ashamed, and contemptible (الخجل), and demanding to continually continuously (استدامة) his heart feel afraid and worried (الوجل). It is a feeling of great fear, so that this feeling of fear can free a servant from negligence (alghoflah). This feeling of fear is also a stimulus for a servant to immediately get out of separation from Allah, and immediately return to mushahadah with Him.

Jazm becomes the actualization of farq in its application in the form of a disconnection (القطع) of the heart from its dependence on other than Allah swt. It can be realized in the elimination (الحدف) of attachment to other than Him, and silence (السكون) in accepting all the consequences that must be implemented in the laws of haqiqat without violating the laws of the Shari'ah.

\section{Stylistics in the Concept of Ma'rifat}

Ma'rifat is one of the teaching concepts in Sufism which is considered the ideals and main goals of the Sufis. Etymologically, ma'rifat means knowledge. So, in the context of Sufism, ma'rifat is a servant's knowledge of the reality of God in his heart (Nata, 1996, pp. 219-220). According to al-Misry, ma'rifat introduces a servant to Allah SWT. This recognition is realized in two ways. The first way is the introduction of a servant to his Lord through the approach of reason (ma'rifat aqliyyah). The second one is the introduction of a servant to his Lord through the approach of the heart (ma'rifat qalbiyyah) (Mahmud, 1966, p. 306).

Al-Ghazali also researched ma'rifat. AlGhazali's skepticism in seeking essential knowledge (ma'rifat) begins with the point of view that knowledge is obtained through the senses. However, Al-Ghazali's findings show that the human senses cannot capture essential knowledge (Al-Ghazali, 1927, p. 55). Like the eye deceived into seeing the sun is so small, while it is bigger than the earth, or to see the shape of a spoon which is believed to be straight, but if it is put in a glass of water, it will look bent. Al-Ghazali's skepticism then led him to believe that proper knowledge can only be obtained through intuition. (Al-Ghazali, n.d., p. 17). 
In short, ma'rifat can fall into the category of maqamat or ahwal. Ma'rifat as one of maqamat means that it is one of the steps of the Sufistic journey of a servant who can be pursued with all abilities (riyadlah). Meanwhile, if ma'rifat is one of the ahwal, it means that it is a gift from Allah that depends on His power and will.

\section{Morphological Stylistics (Word Choice)}

The ism (noun) is divided into ism ma'rifat and ism nakirah. These divisions were also adopted by al-Qushayri in conveying the distinction between the degrees of ma'rifat and nakirah as in the following quote: الأسماء على

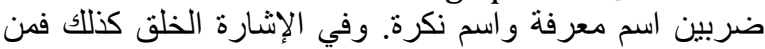

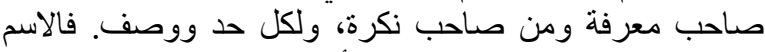

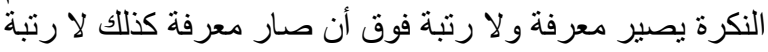
. للعبد فوق العرفان On this occasion, al-Qushayri used the word صاحب to indicate the position of a creature at the level of makrifat and nakirah. This word may suffice with the thulathi mujarrad form of صحب. It seems that there is a specific meaning in the use of the word صاحب which follows the pattern of the form of the word فاعل.

In addition, in the discussion of alma'rifat wa al-nakiroh, al-Qushayri uses the word to indicate the high degree of wisdom. This word can be replaced using لى which has the same meaning as "above". However, according to Rufa'il Nahlah al-Yasu'i, the word $\checkmark \mathrm{is} \mathrm{not} \mathrm{wholly} \mathrm{identical} \mathrm{and} \mathrm{can} \mathrm{replace} \mathrm{the}$ word, because it indicates the existence of something above or the peak of that part of something, while indicates the existence of something above or the peak of something else (Al-Yasu'i, 1989, pp. 154-155).

\section{Syntactic Stylistics (Sentential Style)}

The sentence pattern of taqdim ma haqqahu al-ta'khir is used to form the sentence as an adverb of place that takes precedence, and الخلق كذلك في الارة as the composition of the khabar mubtada ending. While in the following sentence, al-Qushayri removes khobar muqoddam from the sentence in which if the khobar is shown it becomes فمنهما من صاحب معرفة في منة So. man here is man mausulah.

In the following sentence, something rarely used is to make ism majrur with masdariyyah. The word أن صار is used as an ism majrur which is jarred by dharaf in the form of in the sentence فوق و لا رنتة فوق أن صار معرفة. Even though صار is a fi'il (verb), but preceded by أن ان أن it it can be changed ( $\left.t a^{\prime} w i l\right)$ to masdar (صير atau أنّ المخفة (can also be referred to as أن .(صيرورة which functions as 'amil nasikh and its ism (noun) is dlamir sya'n. So, the word صLار is the khabar from أنّ المخفقة. In this sentence, alQushayri also discards one word, namely للإسم. If shown, it will be seen muqabalah (comparison) between the two sentences, و لا رتبة للإسم فوق أن صار معرفة كذلك لا رتبة للعبد namely

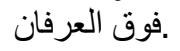

Ma'rifat is a medium for communicating and getting closer to Allah in a very close and good relationship. So aesthetic is the condition of ma'rifat, to the point that al-Qushayri describes that there are commendable and beautiful words. The complete aesthetics in ma'rifatullah can only be realized in a servant's heart. In realizing all communication and munajat a servant can only be operated by the heart. Al-Qushayri also emphasizes that there is no higher degree to be achieved as a servant than ma'rifat. People still in the nakirah stage cannot achieve religious aesthetic values (Hasbiyallah \& Ihsan, 2019, p. 2).

\section{Stylistic Imagery (Tashbih)}

A servant who has climbed the level of ma'rifat billah is always sheltered by good luck and true happiness. This is represented in the concept of ism ghairu munsharif which the author excerpts from the text of Nahw al-Qulub

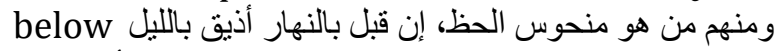
طعم الرد، وإن وافى باليل لحكم الاتفاق تجرع بالغ الغد كأس الصد بالئ "Some of them, there are less fortunate people. Sometimes his worship is accepted during the day but rejected at night. When worshiping at night, the next day, it is like being treated to a glass of water of rejection." The structure of idhafahh كأس الصد (a glass of water of rejection) is a form of tashbih muakkad أب الصد كالكأس. The word الصد (rejection) is likened to (a glass of water). A servant who is lucky in his life in the form of enjoyment obtained and given all the conveniences is beautifully described through metaphor (isti'arah) as walking on a beautiful rug that he wants. Besides, a servant losing money is described with a parable (tashbih) as being treated to all rejection and refusing from Allah which is likened to drinking a glass of rejection water. However, this explanation is not necessarily related to the specific personal characteristics. It shows the aesthetics of al- 
Qushayri's thinking which leads his readers to believe whatever fate they get solely because of the power of Allah. Although there is a chance for a good servant, through his work ethic and maximum effort, he will get rewards and vice versa. It is a realization of human nature based on its existence as a creature who must strive and be responsible.

\section{CONCLUSION}

After describing this research, the researchers draw conclusions based on the comprehensive analyses that have been carried out. The conclusion of this study shows that the esoteric meaning of the nahw rules in al-Qushayri's Nahw al-Qulub is built with at least three foundations of language style full of creativity and aesthetic nuances. Firstly, the language style on the morphological aspect includes the choice of wise words and arouses the reader's taste. Secondly, on the syntactic aspect, the researchers found various forms of unusual patterns or could even be said to violate the rules of mainstream conventional Arabic grammar. The use of khabar with ma mausul becomes a separate and memorable spotlight for researchers because its use was quite frequent. Thirdly, on the imagery aspect, it shows that as a Sufi whose field of focus is on the processing of taste and soul, al-Qushyari also actualizes it in creative imagery forms. It is evident in the many uses of isti'arah and tashbih patterns wrapped in rhyming sentence construction, which inspires the taste and human soul as the reader of his work.

The meanings and messages in question have a sufistic dimension that is very inspiring for the salik in studying Sufism through the field of nahw. In the aspect of extracting meanings and messages born behind the use of language style in Nahw alQulub, it shows that al-Qushayri is one of the Sufi masters engaged in the teachings akhlaqi Sufism. Although on several occasions, data show al-Qushayri alluding to several concepts that are often indicated as the roots of the teachings of philosophical Sufism. Some extractions of meaning from the style of language in Nahw al-Qulub lead to the concepts of takhalli, tahalli, tajalli, self-knowledge with Allah (ma'rifatullah), the greatness of Allah, and appreciation of the sense of His presence in the heart (tajalliyat al-haqq), maqam jama' and farq, as well as various noble moral education in the point of view of Sufism.

\section{REFERENCES}

'Abd al-Karim, A. bin. (2017). Mukasyafah Madluliyyah li 'Alamat al-I'rob fi al-Nah\}wi al-Sufi. Majjallat Al-'Ulum Al-Insaniyyah Universitas Al-Ikhwah Montero, Aljazair, 48.

'Ayyad, S. M. (1992). Madkhal ila 'Ilm al-Uslub. Dar al-'Ulum.

Al-Ghalayaini, M. (1994). Jami' al-Durus al-Lughah al-'Arabiyyah. Dar al-Thaqafah.

Al-Ghazali, A. H. (n.d.). Ihya 'Ulum al-Din. Dar al-Fikr.

Al-Ghazali, A. H. (1927). Mi'yar al-'Ilm. al-Matba'ah al-'Arabiyyah.

Al-Jawziyyah, I. Q. (n.d.). Madarij al-Salikin. Dar al-Kutub al-'Ilmiyyah.

Al-Khafaji, M. A. M. (n.d.). al-Uslubiyyah wa al-Bayan al-'Arabi. Dar al-Mishriyyah al-Lubnaniyyah.

Al-Qushayri, 'Abd al-Karim bin Hawazin. (2008). Nahw al-Qulub al-Saghir wa al-Kabir (A. 'ilm al-D. Al-Jundy \& I. Basuni (eds.)). al-Haiah al-Misriyyah al-'Ammah li al-Kitab.

Al-Yasu'i, R. N. (1989). al-Munjid fi al-Mutaradifat wa al-Mutajanisat (3rd ed.). Dar al-Mashriq.

Anwar, H. (1995). Sufi al-Junaid. Fikahati Aneska. 
Arsyad, A. (2016). Teknik Interpretasi Linguistik dalam Penafsiran al-Quran. Tafsere, 4(2).

Ayim-Aboagye, D. (2018). Fundamental Theorem of The Theory of Superiority Complex. International Journal of Emerging Trends in Science and Technology (IJETST), 5(7).

Carter, M. J. (1997). Mystical Grammar or Grammatical Mysticism? A Sufi Commentary on The Ajurumiyya. Festschrift for Werner Dream, IX, 24.

Hasbiyallah, \& Ihsan, M. N. (2019). Konsep Pengenalan Allah (Ma'rifatullah) Implikasinya terhadap Pendidikan Agama Islam. Jurnal Perspektif, 3(1).

Heck, P. L. (2006). Mysticism as Morality: The Case of Sufism. The Journal of Religious Ethics, 34(2).

Hogendijk, J. P., \& Sabra, A. H. I. (2003). The Enterprise of Science in Islam New Perspectives. The MIT Press Cambridge.

Ibn al-Athi, M. al-D. (2000). al-Nihayah fi Ghorib al-Hadith wa al-Athar ('Ali ibn H\}asan 'Abd al-Hamid (ed.)). Dar Ibn al-Jawzi.

Mahmud, 'Abd al-Qadir. (1966). al-Falsafah al-Sufiyyah. Dar al-Fikr.

Mahpol, S. (2017). The Implementation of Takhalli Value in Arabic Grammar according to AlQushayri in Nahw al-Qulub al-Kabir. Journal of Academic Research in Business and Social Sciences Universiti Sultan Zainal Abidin (UniSZA), 7(12).

Maulana, M. I. (2019). Refleksi Sufistik dalam Nahwu al-Qulub Karya Abu al-Qasim al-Qusyairi. Dialogia: Jurnal Studi Islam Dan Sosial, 17(1).

Miles, M. B., \& Huberman, A. M. (1994). Qualitattive Data Analysis (2nd ed.). SAGE Publications.

Mojaddedi, J. A. (2000). Legitimizing Sufism in al-Qushayri’s “Risala.” Studia Islamica, 90.

Muzakki, A. (2009). Stilistika al-Qur'an Gaya Bahasa al-Qur'an dalam Konteks Komunikasi. Universitas Islam Negeri Maulana Malik Ibrahim Malang Press.

Nata, A. (1996). Akhlak Tasawwuf. Rajawali Press.

Nawafi, M. M. (2017). Eksistensi Majas dalam al-Qur'an sebagai Khazanah Keilmuan Islam. Al-A'raf, $X I V(2)$. https://doi.org/10.22515

Qalyubi, S. (2017). 'Ilm Al-Uslub Stilistika Bahasa dan Sastra Arab (2nd ed.). Idea Press.

Sumarna, L. (2019). Kajian Semiotik Atas Nahw Al-Qulub Karya Al-Qushayri (w. 465/1072). UIN Syarif Hidayatullah Jakarta.

Suyitno. (2018). Metode Penelitian Kualitatif: Konsep, Prinsip dan Operasionalnya. Akademia Pustaka.

Yasin, D. M. (2016). Kajian Stilistika Dalam Teks Al-Mutawassimīn Sebagai Bahan Pembelajaran Mata Kuliah Wajib Stilistika. LINGUA: Journal of Language, Literature and Teaching, 13(2), 195. https://doi.org/10.30957/lingua.v13i2.175

Zahra, N. (2018). Nilai-Nilai Pendidikan Akhlak Tasawuf Menurut Abul Qasim Abdul Karim Hawazin Al Qusyairi dalam Kitab Risalah Al Qusyairiah. Institut Agama Islam Negeri Kudus. 
LiNGUA Vol. 16, No. 2, December 2021 • ISSN 1693-4725 • e-ISSN 2442-3823 